Research Report No. 36/2009

\title{
The Association of Transnational Law Schools' Agora: An Experiment in Graduate Legal Pedagogy
}

Phillip G. Bevans

John McKay

Follow this and additional works at: http://digitalcommons.osgoode.yorku.ca/clpe

\section{Recommended Citation}

Bevans, Phillip G. and McKay, John, "The Association of Transnational Law Schools' Agora: An Experiment in Graduate Legal Pedagogy" (2009). Comparative Research in Law \& Political Economy. Research Paper No. 36/2009.

http://digitalcommons.osgoode.yorku.ca/clpe/148 


\section{Comparative Research in Law \& Political Economy}

CLPE RESEARCH PAPER 36/2009

Phillip Bevans and John McKay

The Association of Transnational Law Schools' Agora: An Experiment in Graduate Legal Pedagogy

EDITORS: Peer Zumbansen (Osgoode Hall Law School, Toronto, Director, Comparative Research in Law and Political Economy, York University), John W. Cioffi (University of California at Riverside), Nassim Nasser (Osgoode Hall Law School, Toronto, Production Editor)

Also available at: http://www.germanlawjournal.com 



\section{German Law Journal}

The Association of Transnational Law Schools' Agora: An Experiment in Graduate Legal Pedagogy

Phillip Bevans and John McKay

10 German Law Journal 929 (2009), available at:

http://www.germanlawjournal.com/article.php?id=1130 and

http://www.germanlawjournal.com/article.php?id=1131

This article was originally published in Volume 10, Number 7 of the German Law Journal as part of the journal's $10^{\text {th }}$ anniversary symposium on "Transnationalizing Legal Education" edited by Nadia Chiesa, Adam de Luca, and Bernadette Maheandiran. 
CLPE Research Paper 36/2009

Vol. 05 No. 06(2009)

\title{
Phillip Bevans and John McKay
}

\section{The Association of Transnational Law Schools' Agora: An Experiment in Graduate Legal Pedagogy}

\begin{abstract}
The Association of Transnational Law Schools [ATLAS] is a consortium of law schools from around the world that launched an annual academic summer program, called the Agora, for doctoral students in July of 2008. The authors outline the history of the creation of the program, describe it, and consider its significance as it relates to the changing landscape of legal practice and pedagogy. The Agora both reflects and furthers a trend in legal scholarship, and as a consequence legal education, toward a focus on a set of interrelated concerns, which include globalization, international governance, transnational law, comparative legal studies, legal transplantation and the apparent conceptual challenges that these pose. In important respects these new conceptual challenges have a long pedigree in questions about the scope of legal pedagogy and theory. The pedagogical controversy is rooted in questions about the purpose of legal education, namely, whether it is trade training and should focus on practical legal skills, or whether it should be conceived of as broader than this. Intimately connected to this pedagogical controversy is a legal-theoretical controversy about the scope of legal theory (and thus the nature of law and its investigation). Does the word "law" designate the organizational instruments of state power, or should we think of "law" as referring to a more diverse set of socialorganizational systems that may have greater or less affinity and connection with state law?
\end{abstract}

Keywords: Legal education, Agora

JEL classification: K10, K40

Phillip Bevans

B.A., LL.B., LL.M., of the Bar of Ontario, Partner, Minden Gross, LLP. Email: PBevans@mindengross.com

John McKay, B.A., M.A., Ph. D., LL.B.

Email: johnsmckay@gmail.com 



\title{
SPECIAL ISSUE: TRANSNATIONALIZING LEGAL EDUCATION
}

\section{The Association of Transnational Law Schools' Agora: An Experiment in Graduate Legal Pedagogy}

\author{
By Phillip G. Bevans and John S. McKay*
}

\section{A. Introduction}

The Association of Transnational Law Schools [ATLAS] is a consortium of seven law schools from four continents that launched an annual academic summer program, called the Agora, for doctoral students this past July 2008. As the name of the consortium would suggest, the program focused on transnational law. ${ }^{1}$ The Agora is one of several multischool initiatives aimed at furthering the study of the globalizing legal environment. The Agora both reflects and furthers a trend in legal scholarship, and as a consequence legal education, toward a focus on a set of interrelated concerns, which include globalization, international governance, transnational law, comparative legal studies, legal transplantation and the apparent conceptual challenges that these pose. ${ }^{2}$ In important

\footnotetext{
* Phillip G. Bevans, B.A., LL.B., LL.M., of the Bar of Ontario, Partner, Minden Gross, LLP. Email: PBevans@mindengross.com, John S. McKay, B.A., M.A., Ph. D., LL.B. Email: johnsmckay@gmail.com. The authors were student participants in the program. Mr. Bevans and Dr. McKay are pursuing the Ph.D. at Osgoode Hall Law School (of York University), where both have also served as Adjunct Professor in the Osgoode professional program. They have both also held other academic appointments. The authors would like to thank Craig Scott and Damien Chalmers for lengthy discussions about the history and mission of ATLAS and the Agora. Thanks are also owed to Cathleen Powell (a fellow doctoral student in the program from South Africa) for her generosity in sharing her notes from the Agora. We are indebted to our home institutions for partially funding our attendance at the Agora. Finally, we owe thanks to Mr. Colin Grey, another fellow Agora participant from NYU, with whom we discussed and worked on this paper in its earlier stages. His help is much appreciated, but any shortcomings of the paper should be attributed to the authors alone.

1 "Transnational law" is a coinage generally attributed to Phillip Jessup. Jessup delivered the prestigious annual Storrs lectures at Yale Law School in 1955. The lectures were published the following year as a short monograph: PHILLIP JeSSUP, TRANSNATIONAL LAW, (1956). Jessup's idea, and the general idea of the ATLAS program, is that the focus on an interlocked system of domestic/municipal law and international law no longer provides an adequate conceptual description of the realities of the legal apparatus that functions within and across borders and functions in ways both more complicated and unanticipated by such a description. On the fiftieth anniversary of their publication, Peer Zumbansen revisited Jessup's Storrs lectures in: Peer Zumbansen, Transnational Law, in THE Elgar ENCYClopedia OF COMPARATIVE LAW, (Jan Smits, ed., 2006); also available at http://ssrn.com/abstract=1105576.

2 The Association's MEMORANDUM OF UNDERSTANDING [MOU] sets out the focus of the program "around the general themes of 'transnational law and governance' and 'comparative law and globalization' (MOU, at 1). The MOU is an internal document to the participating institutions and was 'opened for signature' on October 16, 2007. While the focus on transnationalization is at the core of the ATLAS and the Agora, both in its name and description, the program is conceived as having room for participants who are not wholly focused on issues of
} 
respects these new conceptual challenges have a long pedigree in questions about the scope of legal pedagogy and theory. The pedagogical controversy is rooted in questions about the purpose of legal education, namely, whether it is trade training and should focus on practical legal skills, or whether it should be conceived of as broader than this. Intimately connected to this pedagogical controversy is a legal-theoretical controversy about the scope of legal theory (and thus the nature of law and its investigation). Does the word "law" designate the organizational instruments of state power, or should we think of "law" as referring to a more diverse set of social-organizational systems that may have greater or less affinity and connection with state law?

The paper has three sections. First, we outline the history of the creation of the Agora. Second, we describe, in varying degrees of detail, different elements of the Agora. Finally, we situate the Agora in the context of the scope issue, both as an issue within legal pedagogy, and as a broader question of legal theory generally.

\section{B. History of the ATLAS Consortium}

Law schools around the world have been seeking new ways to present themselves as global institutions, recruiting students from abroad, especially into graduate (LL.M. or equivalent) programs. Several schools offer double-degree programs across national jurisdictions or operate branch locations abroad. Many integrate international, transnational, or comparative law into their core curriculum and now seek to market themselves as "global law schools." Finally, numerous international collaborations have sprung up focused on pushing the study of law beyond parochialism. Examples include the Maastricht European Institute of Transnational Legal Research [METRO] ${ }^{3}$ or the new Center for Transnational Legal Studies in London, ${ }^{4}$ but of course various law schools are

transnationalization, but who may benefit from participating in the program. Member schools are responsible for selecting participants from their own cohort of doctoral students to participate in the program. The selection criteria for participating students are academic excellence and research potential (MOU, at 2). A focus on legal transnationalization, while a desideratum for selection, is not requisite. The consortium is said to be "dedicated to the intellectual formation of highly talented doctoral students and fostering reflection and research on issues broadly related, but not limited, to comparative legal and regulatory responses to various forces of globalization, international governance challenges and the evolution of transnational law." (ATLAS web site, http://www.atlasdoctorate.org, last consulted 10 March 2009).

\footnotetext{
${ }^{3}$ See Metro Research Institute, MAASTRICHT UNIVERSITY, available at: http://www.unimaas.nl/default.asp?template =werkveld.htm\&id=7L70CD0472000M4KAOC7\&taal=en .

${ }^{4}$ The Center is a collaboration between ten law schools from around the world spearheaded by Georgetown University. It is a semestered program aimed at first-degree law students. Center for Transnational Legal Studies, Available at: http://ctls.georgetown.edu/info/index.html\#Newctrtranslegal Another example demonstrating the interest in global law, though not at a law school, is Brown University's Advanced Research Institute in Law, Social Thought and Global Governance, a program for emerging scholars proposed to be held annually, starting in June 2009 available at: http://www.brown.edu/Administration/International_Affairs/initiative/index.html.
} 
involved in any number of bilateral arrangements. ${ }^{5}$ This proliferation in global outreach efforts by law schools around the world reflects developments in the profession and in the legal academy generally, ${ }^{6}$ and, to some extent, the opportunities for collaboration that presented themselves at an increasing number of conferences that have been held in the past ten or more years concerning global law, law practice, and legal education. ${ }^{7}$ Among other things, these resulted in the foundation of the International Association of Law Schools. ${ }^{8}$ Though unique in its focus on doctoral legal students, ATLAS is undoubtedly part of this wider shift toward the globalized study of law. ${ }^{9}$

The ATLAS consortium evolved from discussions in 2002 between Professor Craig Scott, then Associate Dean of Research and Graduate Studies at Osgoode Hall Law School in Toronto, Canada, and Professor Stephen Parker, then Dean at Monash University Law

${ }^{5}$ Among United States law schools alone, Cornell University Law School, Columbia Law School, New York University Law School, American University Washington College of Law, and no doubt others, offer dual degree programs with other law schools in North America, Europe, Asia, and Africa: see Simon Chesterman, The Globalisation of Legal Education, SINGAPORE JOURNAL OF LEGAL STUDIES 58, 63-64 (2008).

${ }^{6}$ Id., 62-65.

${ }^{7}$ Said to be the first multijurisdictional gathering held to discuss transnational services was the 1998 Paris Forum on Transnational Practice for the Legal Profession. A report of this meeting occurs in the following: Laurel Terry, An Introduction to the Paris Forum on Transnational Practice for the Legal Profession. 18 DICKINSON JOURNAL OF INTERNATIONAL LAW, 1 (1999-2000). Other influential conferences include: The American Association of Law Schools ("AALS") Symposium on Emerging Worldwide Strategies in Internationalizing Legal Education held at the AAL Annual Meeting on January 6, 2000 in Washington, D.C.; the AALS Conference of International Legal Educators held at NYU's campus at Villa La Pietra, (in Florence, Italy in 2000 (involving 50 invited legal educators from about 30 different countries) (the "2000 Conference"); the Global Legal Practice Symposium Issue, 22 PENN STATE INTERNATIONAL LAW REVIEW, No. 4 (2003-2004) based on the Global Forum on International Legal Ethics and Rick Management Legal Practice jointly sponsored by the Association of Professional Responsibility Lawyers and the University of Oxford, held in Florence, Italy in October 2002; the American Association of Law Schools Conference on Educating Lawyers for Transnational Challenges held in Hawaii, 26-29 May 2004 (the "2004 Conference"); and the Symposium on Educating Lawyers for Transnational Challenges held at the AALS Annual Meeting in San Francisco in 2005. This last conference was reported in 23 PenN State International LaW ReVieW, No. 4. (20042005). The 2000 Conference was believed to be the first worldwide conference held to discuss international cooperation in legal education. See John Sexton and Carl C. Monk, Papers from the La Pietra Conference of International Legal Educators, 51 JOURNAL OF LEGAL EdUCATION 313 (2001). This volume also contains conference proceedings.

${ }^{8}$ From the 2000 Conference and the 2004 Conference and the AALS 2005 Annual Meeting evolved the meeting in Istanbul, Turkey, in May 2005 at which the International Association of Law Schools was established and then incorporated in October 2005. Craig Scott was a founding member and director, as well as Chair of the Nominating Committee. See also Carl Monk, What Kind of Machinery Can Be Set in Place on an International Basis so that the Process Can Continue in a Constructive Manner in Years Ahead? 23 PENN STATE INTERNATIONAL LAW REVIEW, No.4, 749 (2004-2005).

${ }^{9}$ This raises some conspicuous questions for the program: Is it somehow part of an elite discourse that excludes those marginalized by globalization? Are we seeing not the globalization of legal education, but its global Americanization (Chesterman (note 5) at 65)? These are important questions, which we must, for now, leave aside. 
School in Australia. Scott and Parker explored a vision of collaborative legal education at the graduate level that would focus on transnational law and governance. ${ }^{10}$ As part of this initiative, Scott and Parker sought to involve further partners-first the Universidad de Deusto in Bilbao, Spain and the Université de Montréal in Canada, later bringing in New York University in the United States and the London School of Economics. ${ }^{11}$ Monash dropped out of the consortium in 2007, when Parker left to become Chancellor and President of Canberra University, after which Melbourne joined in its stead. ${ }^{12}$ Later, the University of Cape Town in South Africa joined the group. The consortium is growing with two new members this year - Bar-llan University, Tel Aviv and Bucerius Law School, Hamburg, Germany. The National University of Singapore will be joining ATLAS next year.

The organizers initially contemplated that ATLAS would run courses which would count toward fulfillment of members' master's-level programs. A model was floated in which between fifty and sixty percent of the requirements for a one-year master's degree would be satisfied by credits from a student's home institution, with the balance coming from ATLAS. ATLAS courses would have been delivered over a concentrated period during which students from all consortium schools attended one location for intensive coursework and/or research and writing. ${ }^{13}$

Thus, the Agora was originally contemplated as a for-credit program involving the preparation of a substantial paper, followed by an active on-site program encompassing five weeks intensive work, preceded by a week of reading and orientation and succeeded by a week of evaluation and wind-down. The format would have incorporated full seminars and courses, research seminars, mini- and micro-courses, one-off workshops and panel discussions, negotiation simulations, film/video sessions, student-organized discussions, student working paper presentations, informal discussion evenings, as well as a culminating plenary session. ${ }^{14}$ Presentation of working papers by the students would have been a key component of the program, in order to introduce students to the process of work-shopping their scholarship at a sufficiently early stage to obtain useful feedback.

\footnotetext{
${ }^{10}$ Craig Scott, Transnational Curriculum for Tomorrow's Lawyers - Is There a Curricular Core for the Transnational Lawyer?, (Paper presented at the AALS Conference on Educating Lawyers for Transnational Challenges, Hawaii, 26-29 May 2004) 157.

${ }^{11}$ Interview with Craig Scott conducted on November 28, 2008. Craig Scott is Professor, Osgoode Hall Law School of York University (Associate Dean, Research and Graduate Studies, 2001-2004), Director of the Nathanson Centre on Transnational Human Rights, Crime and Security, Osgoode Hall Law School, and Academic Director, ATLAS, for 2006-2008. (Scott interview).

${ }^{12} / d$.

${ }^{13} / d$.

${ }^{14}$ Scott, supra note 10.
} 
It became apparent as discussions progressed, however, that some participating schools' master's programs did not have enough of a research component for their students to benefit from such an experience. Following a suggestion by Professor Joseph Weiler of NYU at a meeting in 2004, the program's focus shifted to the doctoral level. ${ }^{15}$ This shift eased some of the administrative complications that would have beset an integrated master's program. For instance, as some of the partner schools did not require doctoral students to take many courses (or any at all), it was no longer necessary for student participation in the Agora to be undertaken for degree credit purposes, alleviating scheduling difficulties. Among other things, it was less important that the courses offered attain uniform content and faculty complement that would satisfy the graduate faculties of each of the participating law schools. This made it possible to shorten the Agora to three weeks. Also, because the course content and faculty involved could change from year to year, it became unnecessary to hold the Agora each year at the same (somewhat) centrally located site and involving the same faculty, making it possible to alternate the site among the various law school partners in rotation. In turn, this meant that each year the Agora faculty could be primarily sourced from the partner at whose facility the event was taking place, considerably reducing travel and other commitment costs, and encouraging the participation of partner schools whose resources were more modest.

However, the organizers hoped that each Agora would include significant faculty participation from non-host schools. This was in line with an original ambition of the program to bring faculty together for various forms of collaboration including evening symposia, formal or informal discussions of works-in-progress, sitting in on colleagues' seminars and presentations, and possibly for participation in an annual publication on the particular themes of that year's conference principally written by the professorial faculty for that purpose. It was also anticipated that participation in ATLAS and in the annual Agora would provide an easier path to unexpected interaction among faculty, both at the management and at the professorial levels, as has apparently already transpired. ${ }^{16}$ For example, in at least one case, when a participating school required temporary faculty for a particular summer program by reason of a change in plans of one committed faculty member, that school was able to source a replacement at a late date from among the faculty of another member school.

The rotation of the Agora's location among partner schools was expected to prevent ossification of the curriculum, outlook, and faculty of the annual Agora. It was anticipated that the particular orientation and strengths of each partner would be reflected in the content and methodology of the Agora in the year in which such partner was the host. ${ }^{17} \mathrm{At}$

\footnotetext{
${ }^{15}$ Scott interview, supra note 11.

${ }^{16} / d$.

${ }^{17}$ Id.
} 
the same time, the exposition of the host school's particular perspective each year was expected to enhance scholarly discussion of its own and competing perspectives, on a rolling basis as the host school changed from year to year.

Finally, by focusing on doctoral students the program has an opportunity to fill some of their unique needs. By convening for a brief but intense academic program, students would be given a break from the solitude of dissertation writing and research. It was hoped that the Agora might begin to provide students with certain strategic skills, such as networking or positioning their research product in an attractive way in the academic world. It was thought that most students would be at the end of their first year, so that they could present their work to others before their research agenda was set in stone. Also, it was felt that doctoral students would particularly benefit from exposure to different methodologies in workshops given by faculty from other schools. Finally, the hope was that the Agora would encourage students to think about their research in broader terms and not narrow their focus too quickly.

\section{Account of the Agora}

In what follows we will describe some of the different elements of the program to try to give a sense of the general shape of those elements in a way that is suggestive of their broad strokes and/or outstanding moments. Rather than a mere cataloging of the content of the program, we hope to highlight the content in a way that facilitates an understanding of the argument in the latter part of the paper.

\section{The General Courses}

\section{Introduction}

The themes of the two general courses were "Topics in Transnational Law and Globalizations" (GC1) and "Contemporary Challenges for Corporate Regulation" (GC2). ${ }^{18}$

\footnotetext{
${ }^{18}$ The General Courses divided the cohort of Agora students into two (unevenly sized) groups (with more students in GC1). Students signed up to one or the other course but were free to attend as many sessions of the alternative general course as they desired. (Apart from the Dissertation Research Seminars, which divided the cohort into eight small groups, all other elements of the program were common to all students.) The MOU states that normally one general course will cater to "doctoral students most interested in international law, transnational law and governance, and globalization" while the other will cater to those "most interested in general jurisprudence or common challenges issues faced by domestic legal systems and comparative judicial, legislative and regulatory responses to such issues." ATLAS organizers have described the general intention for this and future Agoras in slightly different terms. In our interview with Craig Scott he suggested the intention was to have one general course deal with issues of a more theoretical nature, and the other of a more practical nature. On the other hand, Professor Damien Chalmers, in our interview with him, suggested the intention was to have one general course deal with transnational issues and the other deal with non-transnational issues. (Interview with Damien Chalmers (LSE), 15 December 2008.)
} 
The focus of GC1 tended towards the changing structures of public international law especially as suggested by the idea of transnationalization. As the world has grown smaller and more interconnected the demands placed on international law, and the claims of state sovereignty and immunity have waned, or, at least, have been challenged as to their legitimacy. This changing reality suggests the need to theorize the global legal terrain differently, understanding the connections between municipal and international law differently, as well as considering the ways in which soft law and non state regulatory forces play a role in the global legal environment.

In GC2, following an introduction that reviewed much of the classic literature on the corporation, the course considered the sundry ways in which corporations, both domestically and on an international scale, (and especially the latter), can be regulated and reigned in from contributing to some of the social ill effects which have historically been attributed to them. Included in this are questions about the propriety, and efficacy of voluntary measures, the means of persuading corporations to take into consideration stakeholders other than shareholders and managers, and possible ways to encourage the democratization of the corporation from within or without.

\section{General Course 1: Topics in Transnational Law and Globalizations}

The opening session of GC $1^{19}$ might have better been a joint session. Professor Zumbansen (Osgoode) argued that globalization would infuse every aspect of the students' future scholarship and teaching, as much for corporate law as for the law of evidence and international law. A similar theme was sounded in a later Distinguished ATLAS Lecture titled "The End of the Globalization Debate, Revisited" by Professor Robert Howse (NYU). ${ }^{20}$

\footnotetext{
${ }^{19}$ ATLAS Lecture, Professor Peer Zumbansen (Osgoode), "Varieties of Globalization and Relationships to Law," 7 July 2008. The readings for the lecture/discussion were: Saskia Sassen, Blind Spots: Towards a Feminist Analytics of Today's Global Economy, Presentation at the University of Wisconsin System Institute for Global Studies (27 September 1999); Joseph E. StiglitZ, MAKING Globalization Work 3-24 (2006); Gunther Teubner, Global Bukowina: Legal Pluralism in the World Society, in Global LAW WITHOUT A STATE 3 (Gunther Teubner ed., 1997).

${ }^{20}$ ATLAS Lecture, Professor Robert Howse (NYU), "The End of the Globalization Debate," (9 July 2008). Professor Howse in his lecture drew on a recent article of his: Robert Howse, The End of the Globalization Debate: A Review Essay, 121 HARVARD LAW REVIEW 1528 (2008). Howse's lecture presented the thesis that the debate over globalization could no longer be framed in terms of pro-globalization and anti-globalization forces. Rather the debate has shifted to one where the stakes are global values and agendas-pertaining to environmental sustainability, human rights, labor standards, and so on-that cannot be advanced by retreating to the nationstate for shelter. The issues being prosecuted are simply beyond the capacity of any country, however powerful, to address by acting alone. Besides, nation-states have themselves been radically transformed by globalization, so it is unclear whether a retreat to the nation-state would in fact be a retreat from globalization. In light of these shifts, Howse in his lecture said he "wanted to tease out for law and legal scholarship what it means to be beyond the globalization debate." That, it seems was the overall aim of the Agora as well. In making this argument Howse drew on the work of Saskia Sassen (SASKIA SASSEN, TERRITORY, AUthORITY, RightS: From MEDIEVAL tO GLOBAL ASSEMBLAGES (2006)).
} 
The second session ${ }^{21}$ focused on ways in which governance and regulation can be asserted through voluntary forms of association. How is authority asserted by non-state actors that propagate regulatory standards in areas like the environment, human rights, and labor relations? A central element of this lecture focused on the work of the International Organization for Standardization (ISO) and its system of voluntary compliance standards. The ISO is an NGO whose members are the national standards institutes of 159 countries. It has a Central Secretariat in Geneva, Switzerland, that coordinates the system. The membership, through the ISO, sets and publishes their various standards. National standardization institutes or other accredited agencies audit companies that subscribe. Compliant companies are certified with respect to the relevant standard and can then use this certification in marketing either to the public or business to business. ${ }^{22}$

Municipal or domestic constitutional law arises through a political process in which the polity strikes an agreement about the legal ground rules. Is there something similar on an international or global scale? Certainly since the time of the formation of the UN, there has arisen an apparently ever-increasing set of legal institutions that function across borders. As international law has evolved and the individual with rights has started to have a place within international law, a question has arisen as to whether the "constitution" of international law is not merely one of international institutions but is grounded in human rights as the bedrock principle in the way many domestic constitutions function. Session three examined these questions. ${ }^{23}$

Sessions four, ${ }^{24}$ six $^{25}$ and eight ${ }^{26}$ focused on legal-theoretical questions dealing with the conception and understanding of transnational law. Each of these sessions, addressed questions concerning how to conceive of the law, and what theoretical accounts of law could help us make sense of the changing field of transnational law. The last section of this paper will examine these questions more closely, and place them within the context of a

\footnotetext{
${ }^{21}$ ATLAS Lecture, Professor Stepan Wood (Osgoode), "Political Economy of Transnational Governance" (9 July 2008).

${ }^{22}$ See International Organization for Standardization, available at: www.iso.org.

${ }^{23}$ ATLAS Lecture, Professors Robert Howse (NYU) and Craig Scott (Osgoode), “Competing Constitutionalist Claims in the International System" (10 July 2008).

${ }^{24}$ ATLAS Lecture, Professor Ruth Buchanan (Osgoode), "Transnational/International Legal Pluralism" (14 July 2008).

${ }^{25}$ ATLAS Lecture, Professor Michael Giudice (York), "Inter-Field Relationships in Public International Law" (18 July 2008).

${ }^{26}$ ATLAS Lecture, Professor Michael Giudice (York), “Conceptualizing Transnational Law” (24 July 2008).
} 
discussion of how these changes in the law fit within and impact a changing conception of legal education. ${ }^{27}$

In session five, Professor Craig Scott examined how international legal norms are received into national legal systems, and, conversely, how national norms are projected out into the international realm. ${ }^{28}$

\section{General Course 2: Contemporary Challenges for Corporate Regulation}

The first two modules in GC2 served as an intensive survey (or review) of the highlights of the legal theory of the corporation, ${ }^{29}$ as well as related matters. ${ }^{30}$ The first class, led by

${ }^{27}$ Session 8 included a reading that did a particularly good job of reviewing the terrain of the issue: Roger Cotterrell, transnational Communities and the CONCEPT of LAW, 21 Ratio JuRIS 1 (March 2008). In this essay Cotterrell outlines "four realistically possible approaches to the conceptualization of law in legal pluralism (at 8)". The four alternatives are (1) monistic - which searches for a "single criterion of law to be applied to the diversity of legal regimes (at 8)", (2) agnostic, (3) statist (which are self-explanatory), and the final option is pluralism. Cotterrell writes: "A final approach would be to rethink the concept of law to free it from biases built into it by its almost universal modern association with nation-state law. Such a concept would not be one that purports to reduce the plurality of transnational regulation to a single, unified system (a surely pointless task at the present time). Nor would it treat state law as necessarily expressing the essential contemporary characteristics of law. Instead, it would adopt criteria of the legal that are sufficiently flexible to recognise many different forms of law in currently indeterminate but potentially developing relations with each other (at 8)."

${ }^{28}$ ATLAS Lecture, Professor Craig Scott (Osgoode), "Receiving the External: Relationships of Foreign and International Law to 'Domestic' Law" (17 July 2008).

${ }^{29}$ Amongst the theories considered were agency theory and "nexus of contracts" theory, (see, for example, M. Jensen and W. Meckling, Theory of the Firm: Managerial Behavior, Agency Costs, and Ownership Structure, 3 Journal of FinANCIAL ECONOMics 305 (1976); E.F. Fama and M. Jensen, Separation of Ownership and Control, 26 JOURNAL OF LAW AND ECONOMICS, No. 2, 301(1983)), stakeholder theory, (e.g., in EdWARD R. FreEMAN, StRATEGIC Management: A Stakeholder Approach (1985), at 53; and Principles of Stakeholder Management, The Clarkson Centre for Business Ethics and Board EFfectiveness, Rotman SCHOol of MANAgement, University of TORONTO, http://www.rotman.utoronto.ca/ccbe/details.aspx?ContentID=215 (last consulted 5 Jan 2009)), "enlightened" stakeholder theory, (see, for example, M. Jensen, Value Maximization, Stakeholder Theory and the Corporate Objective Function, 14 Journal OF APPLIED CORPORATE FINANCE, No. 3, 8 (2001), and team production theory, (see, for example, Margaret M. Blair and Lynn A. Stout, A Team Production Theory of Corporate Law, 85 VIRGINIA LAW REVIEW 247 (1999).

${ }^{30}$ These related matters include contracts and markets and the extent to which the corporation straddles both (as developed, for example, in R.H. Coase, The Nature of the Firm, 16 Economica No.4, 386 (1937); and Oliver Hart, Corporate Governance: Some Theory and Implications, 105 THE ECONOMIC JOURNAL, 690 (1995), transaction cost economics (see, for example, Oliver Williamson, MARKETS AND HIERARCHIES (1975)); and Oliver Williamson, Corporate Governance, 93 YALE LAW JOURNAL NO. 7, 1197 (1984)), value maximization (for example, see Jensen, (note 29)), separation of ownership and control (as prominently outlined by A.A. Berle and G.C. Means, THE Modern Corporation and Private Property, (1932); and discussed, for example, in Fama and Jensen, (note 29); credit for this insight is often given to ADAM SMITH, THE WEALTH OF NATIONS (1832)), conflicts of interest and appropriation of managerial "rents" (see, for example, references cited at note 29, among others), risk management (see one discussion of this in Michael Power, The Risk MANagement of EVerything, (2004) at 7), corporate social disclosure and corporate social responsibility (an early discussion of which appears in Cynthia Williams, The Securities And Exchange Commission And Corporate Social Transparency, 112 HARVARD LAW REVIEW 
Professor Peer Zumbansen (Osgoode) also moved beyond this review to a close reading of the seminal work "Value Maximization, Stakeholder Theory, and the Corporate Objective Function" by Michael Jensen, and then began to situate these concepts in relation to the concept of "transnational law." ${ }^{31}$

The second session led by Peer Zumbansen and Professor Mary Condon (Osgoode), while still introductory in nature, moved beyond the survey and further developed the connection of corporate law and corporate theory to questions of transnational law and legal pluralism. It also considered the seminal work of Ulrich Beck, ${ }^{32}$ (and later Michael Power and others ${ }^{33}$ ), which began the focus on corporate regulation as a matter of assessing risk. Risk assessment and analysis was first adopted in accounting and finance circles, and only later applied to thinking about the legal regulation of the corporation. The shift to risk assessment thinking devalued the role of political discourse and law, and focused on the internal control mechanisms, such as disclosure and organizational culture.

In the case of European integration, ${ }^{34}$ the regulation of any field no longer takes place in a clearly demarcated "public" space as distinct from a "private" one. The development of guidelines, codes of conduct, norms, and certain principles of behavior within and among corporations (rather than publicly) attempts to function in a de-politicized way that tries to abolish the previously dominant left/right characterization of "politics." Integration and harmonization of corporate law between developed countries tends to displace politics in favor of self-regulation, but this "de-politicizing" tendency has also begun to affect the developing world as ideas about harmonization with the corporate law of the developed world spread through the discourse of law and development, and the idea of "best

\footnotetext{
1199 (1999); see also Kent Greenfield, New Principles for Corporate Law, 1 HASTINGS Business LAW JouRnal 87 (2005)), and the divergence/convergence of corporate law and regulation, affected by path dependence and other factors (for example, see Rafael La Porta, Florenzio Lopez-de-Silanes, Andrei Shleifer, and Robert W. Vishny, Legal Determinants of External Finance, 52 Journal of FINANCE No. 3, 1131 (1997); and Rafael La Porta, Florenzio Lopez-de-Silanes, Andrei Shleifer, and Robert W. Vishny, Law and Finance, 106 Journal of Poltical ECONOMY No. 6, 1113 (1998); and other studies by those authors), in jurisdictions embodying different "varieties of capitalism" (see, for example, Ronald Dore, William Lazonick, and Mary O'Sullivan, Varieties of Capitalism in the Twentieth Century, 15 OXFord ReVIeW of ECONOMic Policy No. 4, 56, (1999).

${ }^{31}$ This included a discussion of a challenging paper by Peer Zumbansen in which he argues that European corporate law and regulation can be understood as a manifestation of transnational legal pluralism. Peer Zumbansen, 'New Governance' in European Corporate Law Regulation as Transnational Legal Pluralism, 15 EUROPEAN LAW JOURNAL No.2, 246 (2009).

32 ULRICH BeCK, RISK SOCIETY: TOWARDS A NEW MOdeRnITY, (1992), originally published in German in 1986. See also Barbara adam, Ulrich Beck, and Joost van loon, The Risk Society and Beyond: Critical Issues for Social Theory (2000).

${ }^{33}$ See Power, supra note 30.

${ }^{34}$ See Zumbansen, supra note 31.
} 
practices". ${ }^{35}$ One of the ways in which harmonization (particularly if based on "best practices") fosters de-politicization is the need for expert advice to carry out this process. The reality of different political economies existing across borders, nonetheless, continues to arise as a countervailing pressure in the attempts towards harmonization. ${ }^{36}$

In session three, ${ }^{37}$ two Osgoode faculty presented their own research work related to securities law in Ontario. Mary Condon argued that there is a greater need to identify and promulgate incentives for compliance rather than ex post facto penalties in securities law, ${ }^{38}$ while Marilyn Pilkington argued that sanctions and remedies for breach of securities laws in Ontario (and Canada) are in need of reform to strengthen their effectiveness. ${ }^{39}$ Both lecturers engaged securities law at the domestic (or municipal) and practical level, while also discussing collaborative initiatives among provincial, and (although the focus of a more limited discussion), national and international bodies, both governmental and nongovernmental. Phillip Jessup describes "transnational law" as functioning both within and across borders, so in addressing intra-statal and supra-statal governance, both lecturers were discussing emerging issues of transnational law in corporate regulation. ${ }^{40}$

\footnotetext{
${ }^{35}$ At the same time, within developed countries, such as the European Union, harmonization of corporate law has become a key objective, partly against the background idea that economic integration would be conducive to constitutional cohesion. Nonetheless, at the present time corporate and commercial law in Europe is one of the least harmonized areas of European law, partially because of its embeddedness or path dependent nature.

${ }^{36}$ See the "varieties of capitalism" literature, supra note 30.

${ }^{37}$ ATLAS Lecture, Professor Mary Condon (Osgoode) and Professor Marilyn Pilkington (Osgoode) "Rethinking Enforcement and Litigation in Securities Regulation" (10 July 2008).

${ }^{38}$ Mary Condon, Rethinking Enforcement and Litigation in Ontario Securities Regulation, 32 QUEENS LAW JOURNAL No. 1, 1, 34 (2006). Professor Condon situated her paper in the context of discussions about the proper normative goals of sanctioning by securities regulators, from both a law and economics perspective on the one hand, and a sociological one, on the other. She concluded that there is insufficient evidence to conclude that administrative and criminal sanctions administered ex post facto are effective deterrents to breaches of securities law, and that greater attention must be devoted to reshaping organizational incentives to promote compliance with, rather than breaches of, securities law (at 261). In the short run, however, a mix of private and public enforcement of securities laws, that is, by means of litigation initiated by private parties and by public regulatory authorities, may be appropriate (at 263).

39 Peter Cory and Marilyn Pilkington, Critical Issues in Enforcement (2006), (Research Study), Canada Steps Up: Task Force To Modernize Securities LegisLation In CANADA 165 (September 2006). Professor Pilkington commented on weaknesses that are widely perceived to exist in the enforcement of securities laws in Canada, and, in particular, made recommendations to strengthen the investigation, prosecution and adjudication of securities matters, as well as the recovery by investors of compensation for losses incurred as a result of breach of securities law. This reflected the breadth of research into these matters by various other commissions and enquiries initiated by regulatory authorities and legislative bodies, as well as a significant consultation process which the Task Force undertook.

${ }^{40}$ Jessup, supra note 1.
} 
Subsequent sessions addressed other transnational implications of corporate law. Session four $^{41}$ discussed how disclosure, shareholder proposal and minority proxy solicitation provisions of corporate law can be applied in order to impact human rights issues. Professor Aaron Dhir (Osgoode) demonstrated how careful compliance with the detailed requirements of the statutory and case law applicable to the corporation as a matter of domestic law can assist in achieving corporate social and human rights accountability with respect to operations of the corporation conducted outside the borders of the incorporating jurisdiction. ${ }^{42}$ In a similar vein, Professor David Doorey (York) discussed how it is possible to use corporate disclosure obligations and practices, both voluntary and involuntary, applicable to global supply chains to advance workers' rights in foreign jurisdictions in which suppliers conduct business. ${ }^{43}$

In the penultimate session of GC2 University Professor, former York University President and former Osgoode Dean Harry Arthurs gave a wide-ranging talk on the "construction of legal fields" and on the connections between company and labor law. ${ }^{44}$ Arthurs' question, in short, is why does the legal academy (and why do practitioners) divide up the conceptual terrain of law in just the ways they do? It is a theoretical question that goes to the core of much of the Agora. The short answer is that it is ideological. In a functional approach to the law there are obviously close connections between company and labor law - labor contracts and labor relations are an aspect of running a company. By separating company law from labor law, legal thinkers tend to maintain a focus on the relationship between board, executive and shareholders. The conception of the corporation as a vehicle for maximizing shareholder value, over other possible social conceptions, including treating employees as legitimate stakeholders tends to be pushed

${ }^{41}$ ATLAS Lecture, Professor Aaron Dhir, (Osgoode) "Perspective on Corporate Social Responsibility, Corporate Law and Human Rights," (14 July 2008). His lecture drew on his recent article Realigning The Corporate Building Blocks: Shareholder Proposals as a Vehicle For Achieving Corporate Social and Human Rights Accountability, 43 AMERICAN BUSINESS LAW JOURNAL 365 (2006).

${ }^{42}$ This was also the subject of an early seminal paper by Professor Cynthia Williams (Osgoode) that was included in the materials, see note 30 .

${ }^{43}$ ATLAS Lecture Professor David Doorey (Osgoode) "Global Supply Chains as Foci of Regulation and Activism The Case of Corporate Transparency and the Advancement of Workers' Rights", (16 July 2008). His research indicated that companies disclosing the location of their factories prepare for the event of disclosure by investing in and significantly improving labour practices, monitoring and inspections: Who Made That?: Influencing Foreign Labour Practices Through Reflexive Disclosure Regulation 43 OSGOOdE HALL LAW JOURNAL. (Osgoode Hall L. J.) 354 (2005).

${ }^{44}$ ATLAS Lecture, Professor Harry Arthurs (Osgoode), "The Construction of Legal Fields: (Why) Are Labour Law and Company Law Different Animals?", (July 23, 2008). Professor Arthurs referenced two recent papers which he authored or co-authored: Harry W. Arthurs, Corporate Self-Regulation: Political Economy, State Regulation And Reflexive Labour Law (2008) in RegUlating LABOUR IN THE WAKE Of Globalisation: NeW Challenges, New Institutions (Brian Bercusson and Cynthia Estlund, eds., 2008); and Harry Arthurs and Claire Mumme, From Governance To Political Economy: Insights From A Study Of Relations Between Corporations And Workers, 45 OsGOODE HALL. L. J. 439 (2007). 
out of mind. Arthurs was concise in his presentation, but a wide-ranging discussion ensued. Though several GC1 members attended this probably should have been a crossover meeting. Arthurs' ideas about how to conceptualize the legal terrain will be examined a little more closely in the final section of this essay.

In the final session of GC2, ${ }^{45}$ Professors Allan Hutchinson (Osgoode) and Cynthia Williams (Osgoode) discussed their ideas about the ways in which corporations could become more responsive to the constituents of the polities in which they operate and whose lives they affect in many important ways. Hutchinson discussed ideas about the structural democratization of the corporation. He seemed to suggest a new legislative framework for corporations in which all the "stakeholders," and not just shareholders, would have the possibility of some democratic input into the corporation - though he was less clear about exactly how this would work. Professor Williams, in discussing markets as sites of political activity, described the Equator Principles, which are a voluntary set of environmental and social standards adopted by lenders in respect of financing for development projects. The Equator Principles provide a useful example of how the voluntary adoption of socially beneficial practices can be conducive to collective welfare, both domestically and internationally. ${ }^{46}$

\section{The Joint Session}

In a presentation to both general courses, Professor Gus van Harten (Osgoode) argued that international investment treaties and arbitrations under such treaties amount to the clearest example of what might be thought of as "global administrative law" presently observed. ${ }^{47}$ These treaties permit investor claims against the state concerned without exhausting local remedies, allow claims for damages to be asserted against it, allow the foreign investors to directly seek enforcement of awards against that state before domestic courts, and facilitate forum-shopping. Thus, such treaties are perhaps the closest in conception to "hard law" at the transnational level.

${ }^{45}$ ATLAS Lecture, Professor Allan Hutchison and Professor Cynthia Williams, "Corporate Governance and Democracy" (24 July 2008). The principal text referenced was Allan C. Hutchinson. Little Republics: From Corpocracy To Democracy (2005) in The Companies We KeEP: Corporate Governance For A Democratic Society (Allan C. Hutchinson, ed., 1997).

${ }^{46}$ The Equator Principles are a set of social and environmental standards created by private sector banks and modeled on standards used by the World Bank. The commitment of some 56 banks and other financial institutions financing infrastructure development requires borrowers to comply with environmental standards has had the result that approximately $85 \%$ of new projects of that nature are subject to those principles. www.equator-principles.com

${ }^{47}$ ATLAS Lecture, Profesor Gus Van Harten (Osgoode), “The Transnationalization of Investment Law: Treaty Rights of Corporations and their Implications for Public Law and Public International Law" (22 July 2008). Professor Van Harten's lecture discussed a paper he recently jointly authored: Gus Van Harten and Martin Loughlin, Investment Treaty Arbitration As A Species Of Global Administrative Law, 17 EUROPEAN JOURNAL Of INTERNATIONAL LAW, NO. 1, 121 (2006). 


\section{Methodology Workshops}

The Agora's six methodology workshops covered fieldwork, historical research, collaborative research methods, interdisciplinarity, and electronic research techniques. In one session, ${ }^{48}$ legal historian Douglas Hay (Osgoode) discussed a massive project covering master-and-servant legislation, the precursor of modern labor law, in the British Empire from 1562 to $1955 .{ }^{49}$ Such a massive undertaking required teams of researchers to spend years combing the legislative record around the Commonwealth, and to develop new computer applications to analyze their findings. Developing this degree of intimate knowledge of such wide ranging (over time and space), but intimately connected, pieces of legislation, helps to throw light upon the processes of legal transplantation, and demonstrated that the ways in which such transplantation flows do not always follow the simplest and more generally accepted pattern of transmission from motherland to colony. Hay, and the session, challenged students to think big about future projects, and to reconsider the mechanics of gathering, organizing and interpreting historical data for future work.

In another session, ${ }^{50}$ Janet Mosher (Osgoode) described how she collaborated on a sixmember team of academics and community workers to produce a report on the overwhelmingly negative experience of abused women seeking government social assistance (welfare) in Ontario. ${ }^{51}$ The report's findings were based on sixty-four interviews with welfare recipients, as well as on questionnaires circulated to welfare administrators. The authors circulated a draft of their findings among forty interviewees, front-line shelter workers, and social advocates and then held an all-day forum so they could get input. ${ }^{52}$ Mosher's work suggested that legal scholarship might sometimes involve the advancement of community-oriented projects with clear programmatic aims.

\section{Dissertation Research Seminars}

\footnotetext{
${ }^{48}$ ATLAS Methodology Workshop, Professor Doug Hay (Osgoode), “Engaging in Field Work: From Planning to Interpreting Results".

49 Douglas Hay and Paul Craven, Introduction, in Masters, Servants And MAgISTRATes In Britain And The Empire: 1652-1955 (Douglas Hay and Paul Craven, eds. 2004).

${ }^{50}$ ATLAS Methodology Workshop, Professor Janet Mosher (Osgoode), "The Politics of Collaborative Research" (15 July 2008). Professor Mosher commented on various types of community-based participatory research (CBPR), and referenced, by way of example, the discussion by Meredith Minkler in Community-Based Research Partnerships: Challenges And Opportunities, 82 Journal Of URban Health: Bulletin Of The New York Academy Of MEDICINE, NO. 2, SUPPLEMENT 2 (2005).

${ }^{51}$ Woman and Abuse Welfare Research Project, Walking on Eggshells: Abused Women's Experiences of Ontario's WELFARE SYSTEM (2004).

${ }^{52}$ Id. at $11-12$.
} 
In one of the most valuable elements of the Agora, participants were required to submit an original piece of research writing, preferably a dissertation chapter, three weeks prior to the commencement of the program to be work shopped in the DRS. The dissertation seminars divided the cohort into groups of about 5 to 8 students each with one or two faculty facilitators. During any given two hour meeting, the group focused on the writing of one student, which all participants had read in advance. The presenting student began with a brief presentation, frequently locating the material presented into the conception of the larger project, i.e., the dissertation. The rest of the time was dedicated to a critical discussion of the sample piece of writing. This could vary from elements of the structure of the argument to questions about aspects of the substance of the argument.

Based on our experience and talks with our classmates, the DRS was one of the most valuable portions of the program - it set a deadline and drove the students to make substantive progress on a portion of the dissertation project. This assessment of the importance of the DRS was generally borne out by the results of an evaluation questionnaire filled out by participants at the end of the program. Students found that not only the feedback on their own work, but also the exposure to the work of others was valuable. Among the other noteworthy elements of the program noted in the questionnaires, students praised the highly interactive, cooperative and collegial nature of the program, providing a genuinely collective learning and intellectual environment. They found the subject-matter, instruction, faculty and their fellow participants to be challenging, diverse, intense, stimulating and multi-national. Many students found the social interaction with faculty and classmates a welcome change that it provided energy, inspiration and criticism of and for their own work, especially at a point in their program and in the year (the summer) at which this was particularly helpful. Not surprisingly, most participants planned academic careers and felt that the Agora contributed to their attainment of that objective.

\section{Film Nights}

The Agora included a small film series (four films, and two related seminars) that worked as an extended law and culture essay organized by Craig Scott. The films all address the complicated questions of the rule of law in intercultural conflict or different forms of war. ${ }^{53}$ These questions engage the concept of transnational law. Even more significantly, such questions strike at the very nature of law, whether conceived as a transcendent normative order, or as a result of constructing polities. Many consider it to be in the very nature of law that it must actively confront this vivid tension. Its legitimacy must come from group agreement, and from some determination of the good for humankind. The films offer a

\footnotetext{
${ }^{53}$ Among other things, they ask what are the lawful or otherwise appropriate limits of police or other governance powers in asserting control or dominance, such as by way of colonialism? Or, contrariwise, what are the limits of violence in resisting colonial or other oppression?
} 
concrete contextualization through which to puzzle with these otherwise abstract questions.

At the core of the program was the 1966 classic The Battle of Algiers ${ }^{54}$ by Italian director Gillo Pontecorvo. Made within a few short years of the end of the Algerian War of Independence from France (1954-1962), it tells the story of the seminal events of the first guerrilla organization and battles in the city of Algiers. ${ }^{55}$ It starkly depicts the rebel actions of assassinations of police officers and terrorist bombings, and the French colonialist actions of bombing and torture (as an intelligence-generating technique).

Two of the other films in the series were closely related. The first was Gillo Pontecorvo: The Dictatorship of Truth (1992), ${ }^{56}$ which is a documentary primarily consisting of interviews with key figures of the Algerian war (on both sides) represented in The Battle of Algiers. A French official describes how the techniques of counter-insurgency and "advanced interrogation" (otherwise known as torture) practiced in many places in the world today have their roots in methods learned by members of the French resistance during WWII in their struggle against the German occupation. The film illustrates that what the French fighters suffered, as insurgents, at the hands of German interrogators they then turned, as representatives of the occupying authority, against the Algerian "freedom" fighters.

The second film was Marie-Monique Robin's 2003 documentary Death Squadrons: The French School, ${ }^{57}$ which is an examination of the ongoing influence of the techniques of counter-subversive warfare developed in Algeria and Indochina. It examines how these techniques travelled from French colonies to the United States (focused on the School of the Americas), and thence, directly and indirectly, to Latin America. French training in counterinsurgency tactics began as early as 1958, and the following year France opened a military mission in Buenos Aires staffed with Algerian veterans that trained Americans and others. Later, at Fort Bragg, French instructors taught such techniques to Vietnam bound members of the American Special Forces for the so-called Phoenix Program. The film describes how French operatives were also involved in Operation Condor, the covert intelligence network maintained among the Latin American military regimes with the

\footnotetext{
${ }^{54}$ Gillo Pontecorvo, (director), The Battle of Algiers, [Italian: La battaglia de Algeri] (1966), premiere at the Venice Film Festival of 1966, now available on DVD from the Criterion Collection.

${ }^{55}$ Pontecorvo shoots on location in Algiers where the battles took place, and even uses some of the key figures of the war as actors playing themselves, reprising their roles for the camera. The film variously described as Italian neo-realist or French cinéma vérité is shot in black and white and presents itself, stylistically, as documentary, despite its staging. The frequently praised and studied film splits its point of view between the Algerian rebels and French colonialists.

${ }^{56}$ Oliver Curtis, (director), Gillo Pontecorvo: The Dictatorship of Truth (1992), Edward Said, narrator. This film is included in the Criterion Collection Box Set under the title "The Battle of Algiers."

${ }^{57}$ Marie-Monique Robin, (director), Death Squadrons: The French School, Icarus Films, 2004.
} 
objective of hunting down and murdering "terrorists" and political rivals wherever they were found, including France where the French government provided assistance for these actions. $^{58}$

War functions at the very fringes of law despite law's claim to govern war and its techniques. In tracing the spread of illegal techniques through government exchange programs that are designed to assure the capacity of legitimate governments to defend themselves against insurgents, the films displayed the ragged edge of defending legitimacy through illegitimate means. The theme of legal transplants, or the spread of legal ideas from one jurisdiction to another, was recurrent in the Agora. What is clear, however, is that the mimetic spread of legal ideas must be juxtaposed to the similar spread of counterlegal thinking.

In the discussion following the films, the participants explored what is often considered as one logical conclusion of such thinking: Guantanamo and its secret sister prisons. Following 9/11, the United States deemed itself to be under worldwide attack by terrorists, or "unlawful enemy combatants" who, as non-state actors, it did not consider to enjoy the protections of the Geneva Conventions, specifically Article 3. Some commentators have maintained that the logic of insurrection threatening the existence of law and the polity is ultimately deconstructed by the recent US actions in an argument that we could only call extensio ad absurdum: that when spread so widely the internal logic that seemed to hold together the argument of protecting legitimacy through illegitimacy just simply breaks down into a complete absence of legality, or even anarchy. ${ }^{59}$

\footnotetext{
${ }^{58}$ Included the film series was an apparent outlier, One Dead Indian, Tim Southam (director), about the shooting death of a native Canadian (Indian) protester at Ipperwash, Ontario, Canada. The film is based on the book by Peter EdWARds, One Dead Indian: The Premier, The Police, AND the IPPerwash CRISIs, (2003). The film tells the story of resistance to colonialism by native Canadian protesters that results in the tragic death of a protester, Dudley George, apparently at the orders of an impatient head of government. At the outbreak of WWII the government of Canada confiscated land to which natives held title, on an interim basis, to use as a military training camp. Fifty years later the land had been turned into a Provincial Park, but still not returned to its rightful owners. To assert their claim to recover their property natives blockaded the confiscated lands. Although the occupation was peaceful, a riot squad and heavily armed tactical unit dispatched by the Ontario Provincial Police entered the park at night. Apparently misinformed about the threats they faced, and perceiving some apparent violence from the protesters, the police opened fire on protesters whose weapons were later said to consist only of rocks and pieces of wood. In the course of these actions native protester Dudley George was killed. One key concern that arose concerning the incident was the extent to which the police actions were influenced by the head of the Ontario Government (Premier Michael Harris), and whether or not he ordered the police to take action without regard to consequences.

${ }^{59}$ In a recent book, (THE WAY OF THE WORLD: A STORY OF TRUTH AND HOPE IN AN AGE OF EXTREMISM, (2008)), Ron Suskind lays bare this reductio or extensio argument in stark terms. He describes how Abdul Hamid al-Ghizzawi, an Afghani baker, ends up in the clutches of the US forces and detained in Guantanamo, where he languished in failing health and with inadequate care despite the near complete absence of any incriminating evidence. His capture took place in the early days of the US invasion of Afghanistan following a leafleting program encouraging Afghans to turn in "terrorists" or Taliban in exchange for benefits for their village communities. Al-Ghizzawi, like others, was detained and remained in detention despite what Suskind maintains to be the utter lack of evidence
} 
Political violence, often in the name of safeguarding the possibility of law, spreads and finds its own justifications. "Unlawful rebellions" may invite the dismissal of "the rules of war" by the dominant power in the face of the need to protect citizens. Yet the postwar history of Algeria shows the victorious Algerian leaders quite capable of employing the selfsame tools of torture, violence and murder in an ultimately unsuccessful quest to retain authority and suppress an attempted coup by fellow Algerians.

\section{Informal Discussion Evenings}

There were other elements of interest, some only briefly alluded to in the description of the Agora so far. Among the most dynamic were the Informal Discussion Evenings (IDE) in which faculty would briefly introduce a topic and readings, after which a free form discussion would ensue. Indeed, while the other elements all involved free discussion and interaction, it was in this forum that faculty and graduate students seemed to most cut loose and explore, and sometimes "thrash out" and even argue ideas together. One IDE session was on the topic of legal transplantation. ${ }^{60}$ As noted previously, legal transplantation was an important and recurrent topic throughout the course of the Agora. Particularly interesting in this IDE was the perspective of Professor Neil Brooks (Osgoode) who shared his experiences as a consultant to numerous foreign (i.e., non-Canadian) governments on revising their tax laws. From Brooks' perspective this is a perfectly natural and unproblematic thing to do. Tax law, he suggested, has essentially the same objectives and functions in essentially the same way everywhere. The only issues are about which elements to implement in order to achieve any given set of policy goals. His ideas about unproblematic transferability, which were likely stated so as to be controversial and provoke debate, raised a great deal of concern and dissent amongst the students and a lively discussion ensued.

\section{Legal Theory and Pedagogy: The Agora and the Scope of Law}

As we noted in the introduction, the Agora both reflects and furthers a trend in legal scholarship and pedagogy related to the scope of both of these. In this last section we will expand on what we mean by this. The pedagogical controversy is rooted in questions about the purpose of legal education, namely, whether it is trade training and should focus on practical legal skills, or whether it should be conceived of as broader than this. This pedagogical controversy is intimately connected with a controversy about the scope of

against him. The story of al-Ghizzawi is also available in audio format in a radio interview Suskind gives on the CBC program "As it Happens," Dec 10, 2008 (part 2), audio available at: http://www.cbc.ca/mrl3/8752/ asithappens/20081210-aih-2.wmv.

${ }^{60}$ ATLAS IDE, Neil Brooks (Osgoode), Jinyan Li (Osgoode), Peer Zumbansen (Osgoode), “Exporting Law: The Challenges and Problems of 'Legal Transplants'” (10 July 2008). 
legal theory and law. There are different ways of conceiving of law and different accounts of what the object of investigation for a legal scholar is. Does the word "law" designate the organizational instruments of state power, or should we think of "law" as referring to a more diverse set of social-organizational systems that may have greater or less affinity and connection with state law? The distinction can be summed up as the difference between a positivist account of law as a certain set of state institutions, and a more sociological account that finds many different "law-like" institutions overlapping each other whose sources of power or legitimacy and whose boundaries do not correspond neatly with those of the state and its law.

Despite their intimate connection these controversies are not about precisely the same issue. Nor is it the case that choosing sides in either of these controversies settles normative issues about what particular laws or forms of law are desirable for the human good. It is likely the case, however, that choosing the side of a more sociologically oriented jurisprudence in the legal theoretical argument will tend to push one to favor a broader curriculum in legal education. But even this does not follow necessarily. One might think that there is a wide range of law-like phenomena that are neither exactly state nor international law, and which are interesting objects of investigation and important forces in the world, and yet think that a law school curriculum (at least in a professional program) should focus on the institutions, doctrine and practices of state law to the exclusion of those other phenomena. But such a position is clearly not that of the Agora, and seems to be less and less frequently the view taken in law school curricula. This is connected to the changing nature of the institution, the changing nature of the legal world, and some good critical/normative reasons for thinking that the broader view helps produce a better legal world and better legal actors. In the rest of this section we will discuss these three factors (roughly) in turn.

There is a long running controversy about the scope of legal education that one can trace through the history of legal education in the western world. In the US, for instance, the history of professional legal education is one in which at first apprenticeships dominate, but this gradually gives rise to schools run by practitioners, ${ }^{61}$ stand alone law schools, and then law schools in universities. ${ }^{62}$ This history also describes an arc of increasingly longer

\footnotetext{
${ }^{61}$ Gail Hupper, the Rise of an Academic Doctorate in law: Origins Through World War II, Boston College law SCHOOL RESEARCH PAPER No. 128. Available at SSRN: http://ssrn.com/abstract=975257 at 7.

62 See, for instance, Brian Moline, Early American Legal Education, 42 WASHBURN LAW JOURNAL, No. 4, 775 (2004). "Although it was a distinct improvement over the apprenticeship and independent law school models, the university law school, pioneered by Story [US Supreme Court Justice and early member of Harvard Law School faculty] and his predecessors, still maintained a basic trade school approach. Blackstone, Jefferson, and Kent had envisioned the study of law as part of a liberal education. But the early law schools maintained no connection between liberal and legal education. Harvard Law School did not require any preliminary education, not even the basic requirements for admission to college. Not until the 1870 s did the law schools begin to establish liberal education requirements, and not until after World War II were any serious efforts undertaken to adopt a
} 
and more onerous courses of formal professional education. The scope controversy, in its simplest form, is about the purposes, content, and form of legal education. On one side, legal education is conceived of as training in a trade, the core of which should embrace practical skills and apprenticeship. On the other side is the notion that training lawyers, especially once law schools have become elements of a university, is about much more than trade skills. Adherents of this view hold that legal education should be broad and should include "cultural" elements, which are also necessary for good lawyering, quite beyond the possession of a defined set of "skills". ${ }^{63}$ Obviously as programs become longer and settled in university-based institutions the tendency to argue for broader scope as a desideratum increases, but even in that context there are many who argue for depth rather than breadth. In North America where admission to professional legal education requires a first university degree those who would argue for a narrow focus can point to that previous education as what should provide access to "other" kinds of knowledge. In many jurisdictions, including Canada, there is an apprenticeship requirement added on to professional legal education, which should seem to allow for the possibility of greater scope in such professional programs. ${ }^{64}$

The question of scope might seem to be completely different in post-professional graduate education, but the goals and purposes of such degrees are frequently bound up with professional education and the purposes of law schools. The general assumption has frequently been that such degrees are for the purpose of educating law professors. This is the case from what is apparently the first scholarly discussion of graduate legal education ${ }^{65}$ by the then Dean of Harvard Law school, Erwin Griswold, ${ }^{66}$ and in the work of McDowell and Mewett ${ }^{67}$ who made the same assumption, though they found the programs at that

comprehensive legal education system, integrating theory and practice (at 50)." Citing, ALBERT J. HARNO, LEGAL Education in the United States: A Report Prepared for the Survey of the Legal Profession, (1953[2004 reprint]).

${ }^{63}$ For a recent discussion of the role of a "liberal education" as a necessary part of the formation of lawyers within law schools see the following interconnected articles: Wesley Pue, Legal Education's Mission, 42 The Law Teacher, No. 3, 270 (2008); (also at SSRN: http://ssrn.com/abstract=1282172); (Pue notes, "From the origins of "modern" legal education at Queen's College, Birmingham, in the mid nineteenth century, university legal education has sought to provide a practically useful, pragmatic, trade training, as part of a liberal education (at 7, cited to SSRN, italics in original)."; Roger Burridge and Julian Webb, The Values of Common Law Legal Education: Rethinking Rules, Responsibilities, Relationships and Roles in the Law School, 10 LEGAL ETHICS, No. 1, 72 (2008); Fiona Cownie, Alternative Values in Legal Education, 6 LEgAL EtHics No. 2, 159 (2003); W. Wesley Pue, Educating the Total Jurist, 8 LEgAL ETHICS No. 2, 208 (2005).

${ }^{64}$ On this point see Pue, 2008, at 13, supra note 63.

${ }^{65}$ As indicated in Sanjeev S. Anand, Canadian Graduate Legal Education: Past, Present and Future, 27 Dalhousie Law Journal 55 (2004).

${ }^{66}$ Erwin N. Griswold, Graduate Study In Law, 28 CANADIAN BAR REVIEW, 267, 272 (1950).

${ }^{67}$ Banks McDowell Jr., and A.W. Mewett, What Are Teachers Made Of? A Critical Appraisal Of Graduate Study In The United States, 8 Journal Of LEGAL EduCATION 79 (1955). 
time in the US wanting. Their assessment of both LL.M. (the typical terminal degree at the time) and doctorates then offered by American universities was that they provided insufficient training for law professors, with the LL.M. being primarily coursework degrees. They thought such programs should include the philosophical background of the law teacher's area of interest to help her clarify thinking about doctrine and its basis, to provide a strong understanding of legal analysis and method, and the ability to view the law as a holistic system embracing certain social objectives. ${ }^{68}$ Thus, they felt that law teachers should be required to study jurisprudence, the relationships between law and other fields of knowledge, and comparative law. ${ }^{69}$

Tracing the rise of the academic doctorate in law in the US starting in the late nineteenth century, Gail Hupper argues that we can see such programs adopting ideas from continental European models of graduate legal education. There are three key ideas imported from Europe: the idea of law as a "science" involving logically deducible and applicable principles similar to those in other fields of study at universities; the rise of the full-time law professor, rather than part-time instructors who were primarily legal practitioners who taught law as a subordinate activity; and the idea of advanced study for individuals who hoped to become legal scholars, as would be undertaken by those planning to become scholars in other disciplines. ${ }^{70}$ She suggests that these developments "meshed well with a fourth phenomenon of the era: a call for lawyers equipped to handle the increasingly complex legal needs of a rapidly industrializing nation." ${ }^{71}$ In this context, "research" was increasingly seen as involving something other than the discovery and elucidation of doctrine, but, instead, as making sense, and contributing to the rationalization, of law. ${ }^{72}$ Much of this research agenda was functional, in that it aimed to "attempt to understand law in terms of its factual content and economic and social consequences." ${ }^{73}$ While different law faculties approached the function of law from "legal realist," "sociological jurisprudence" or "law in action" perspectives, each involved the pursuit of a research agenda. As law schools became more closely integrated with their host universities, which sometimes involved collaboration with scholars in other disciplines, it became apparent that legal scholars, like scholars in other areas, were expected to display some similar values and to undertake somewhat similar activities, including research. Thus, research, whether interdisciplinary or otherwise, became an

${ }^{68} / d$., at 82 .

${ }^{69}$ Id., at $85-86$.

${ }^{70}$ Hupper, supra note 61 at 4.

${ }^{71}$ Id., at 5.

${ }^{72}$ Id., at 24-25.

${ }^{73}$ Laura Kalman, Legal Realism At Yale 1927-1960 (1986), at 3. 
activity in which law teachers were expected to be involved. ${ }^{74}$ Eventually, by the early 1930s, a number of law schools were offering research-based doctorates. ${ }^{75}$ In part, this facilitated the training of lawyers to enter an increasingly complex and professionalized field of practice, but it also facilitated the development of researchers and those adopting more academic approaches to law, and often these scholars were also interested in teaching law. ${ }^{76}$ While many professors at American law schools still have only first law degrees (although often from the most prestigious law schools), many have doctoral degrees as well, while an increasing number have at least an LL.M. ${ }^{77}$ The number of law faculty members with doctoral degrees in law is increasing, and a doctoral degree in law is thought to provide its holder with additional credibility, in terms of certification of research and academic expertise and capabilities. ${ }^{78}$

Hupper suggests that legal doctoral programs fall into three principal categories, in terms of their concentration: firstly, theoretical or interdisciplinary, secondly, doctrinal, and thirdly, policy pragmatist. The first, which she says appears most often at Columbia, Harvard, Michigan, NYU and Yale, involves "work that inquires into the fundamental nature of legal rules and the social, political, economic and institutional context in which they operate." ${ }^{79}$ The second, found most often at George Washington and Wisconsin, according to her, focuses on the rules in themselves, whether in isolation or as applied to a particular problem. $^{80}$ The third, which she says can be found at all the schools mentioned, involves a significant level of doctrinal content, but also discusses the political, economic or technical context in which the rules operate, although without engaging the context or the operation of law in that context from a theoretical or systematic perspective. ${ }^{81}, 82$

${ }^{74}$ Hupper, supra note 61 , at 26.

${ }^{75}$ Id., at 30 .

${ }^{76} / d$., at 31 .

${ }^{77} / d$., at 17.

${ }^{78} / d$., at 23.

${ }^{79}$ GAIL HUPPER, The Academic Doctorate in Law: A Vehicle for Legal Transplants?, Boston CollegE LAW SCHOOL LEGAL StUdIES ReSEARCH PAPER No. 155. Available at SSRN: http://ssrn.com/abstract=1126358) at 24.

${ }^{80} / d$., at 32 .

${ }^{81} / d$., at 35 .

${ }^{82}$ Gail Hupper describes the development of post-professional graduate degrees in law in the US as a borrowing or transplant from Europe (Hupper, supra note 61). In this article she notes that there arises a "missionary" function in these schools of spreading their own conceptions of legal theory (at 9). In another article (Hupper (note 79)) Hupper attributes such zeal particularly to Roscoe Pound, Dean at Harvard Law, in his efforts to spread legal realism throughout American law schools (at 5). Of course, in turning out graduates who would go on to teach at other schools a graduate program could spread its theoretical perspective. There is, of course, a similar phenomenon in other disciplines. (Citation of Gail Hupper articles with permission of the author. Our thanks to her.) 
Several issues drive the theoretical concerns of different schools. However, at the core are persistent issues about differing conceptions of both the law and legal education. Questions about pedagogy can be important drivers of these controversies and the question of the scope of legal education is at the very root of much controversy. As professional training undergoes the shift from apprenticeship (and supplements to apprenticeship) that remain narrowly focused to programs that are university based with the possibility of being much broader, those responsible for these programs begin to ask: What should a lawyer in training learn beyond the basics, i.e. purely doctrinal matters? There are different possible ways to approach this question, and in this way theoretical questions about the law become intimately connected to the professional curriculum. As Kathleen Sullivan notes, "legal rules and opinions are always implicitly theorized." ${ }^{83}$ In a similar way legal pedagogy also entails a theory of law, even if in this context too the theory is left implicit.

Some version of positivism has dominated as a theoretical conception of the nature of law in schools of the common law almost since the creation of such entities. It is worth recalling that HLA Hart's seminal and influential The Concept of Law $^{84}$ was written as a primer for undergraduate/professional students to theoretical thinking about the law. Modern positivism focuses on the idea of law as a product of political convention of states. Law is a social fact. But the analysis offered by Hart and his theoretical successors focuses on understanding law from its own internal logic. In short, assume the reality of the political compromises that create the legal institutions (a neither difficult nor unreasonable proposition) and try to understand how the normative thinking within this enterprise works. This is a valuable, and indeed powerful way of conceiving of the job of legal theory, and especially so in the context of educating professional lawyers. But, despite its power and utility, positivism is also too limited in scope when trying to understand different aspects of the law. This too-limited scope is manifest in two important ways. First is the (geographic) range, and the second is in the epistemic conception.

Built on a foundation of social contractarianism positivism describes law as a product of political compromise that is co-extensive with the state. Such a description works well as a heuristic for lawyers and law students to focus the mind on acceptable sources of law and argumentation in domestic courts. It, however, does not seem to leave much room for analysis of the plural normative order we inhabit. Positivists are not ignorant of the plural normative order, but tend to not think of it as law. Thus H.L.A. Hart thinks of international law as not quite law, though almost. At least international law leans directly upon the forms of law positivists recognize, and includes at least some of the standard hallmarks of law. Other normative law-like forms within and across state boundaries are even further from recognition by positivists, and so they leave them unanalyzed. This is true whether

\footnotetext{
${ }^{83}$ Kathleen Sullivan, Foreword: Interdisciplinarity, 100 MiCHIGAN LAW REVIEW, No. 6, 1217, (2002) at 1220.

${ }^{84}$ Herbert HART, The CONCEPT OF LAW (1961).
} 
we are speaking of localized customary law inside the bounds of weaker states, or forms of international regulation or non-traditional international law. ${ }^{85}$ By one description, then, the positivist takes a limited view of the terrain restricting her view to the law of the bounded state. By another description we might think of the positivist's take on the law not as geographically limited, but as epistemically limited. The positivist may recognize the existence of a plural normative universe, but does not think that the terrain so described is worthy of examination by those concerned with the law. Those other normative orders are not law, says the positivist, and thus not our concern as lawyers or legal theorists.

There are important cross currents to this dominant strain of legal theory in the world of legal pedagogy. Programs like the Agora are an aspect of more recent developments in the area of transnational law. But even without looking to plural normative orders as law (beyond the idea of the state law of the social contract), there are other models offered for understanding the law. In the first half of the $20^{\text {th }}$ century in the US American Legal Realism offers another account of how to think about the law. Realism plays an important role in schools of the common law, especially Yale, in changing thinking about what the jobs of legal theory and pedagogy are. Realism is similar to positivism in its assessment of law as a social fact. It differs considerably, however, in the weight it would give to the political compromise that is the state, and in a normative assessment that functions within state institutions. Realists are skeptical that the law of the state should simply be taken as the model of law. As a social fact, we should understand law to be just whatever happens to function as law. Realists are thus pluralists. An early work of American legal realism describes the system of the law of the Cheyenne tribe - a system of law of a people who live entirely within the confines of the United States and its legal system. ${ }^{86}$ Realists are also skeptical of the idea of assuming that an analysis of legal decision making based on the norms that the legal system proclaims is likely to offer the greatest insight into the functioning of the legal system or judicial decisions. Whatever complex elements cause the transformation of law, or the rendering of decisions, are just those elements that should be considered and analyzed. The realist joke about judicial decision-making is that it is determined by what the judge had for breakfast. But in fact the realist perspective is both

\footnotetext{
${ }^{85}$ Localized customary law within internationally recognized states exists frequently and in different forms, e.g., tribal law, religious law or localized law in shantytowns. The classic account of the latter is Boaventura de Sousa Santos, Law of The Oppressed: The Construction And Reproduction Of Legality in Pasargada, 12 LAW AND SOCIETY REVIEW 5 (1977). There are different forms of international regulation that are not part of state law. Lex Mercatoria in which counterparties in international commerce agree on private arbitrators is one example. This is discussed in Gunther Teubner, Global Bukowina, (note 19). The International Organization for Standardization (ISO) (see note 22) represents another form of transnational regulation that is voluntarily entered into by private business actors, as discussed by Stepan Wood in his GC1 session entitled, "Political Economy of Transnational Governance" (note 21). And, finally, the extent to which international law deals exclusively with sovereign states as having legal personality is giving way to forms of international law that reach within the domains of sovereign states, as we see especially with respect to international criminal and human rights law, suggesting the possible rise of transnational constitutionalism - a recurrent theme in the Agora.
}

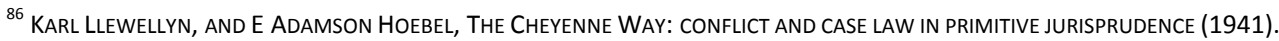


more hard-nosed and more pragmatic in its thinking about law than positivism. If something looks and acts like law, or regulation, then it is law, and worthy of our consideration. And, these law-like things effectuate policies. Whatever considerations help us understand how these policies are created and whether or not they work are also worthy of consideration.

One possible interpretation of what the Agora and its ilk represent is that they are a reemergence of legal realist thinking within the new context of a much more globally integrated system of "legal" activities in response to all the other elements of increasing global integration: financial flows, supply chains, labor markets, environmental impacts, epidemiological concerns, etc. The focus of much earlier American Legal Realism was on the functioning of state law as an instantiation of a particular social contract. As a (social) scientist looking at the legal terrain, a realist perspective is invaluable. ${ }^{87}$ It offers a fuller understanding than a positivist conception of law when trying to think of the "legal" terrain of global regulatory activity. So, if we think of the positivist account as offering a useful heuristic within a certain context, rather than defining a limit to what counts as "law," then there need be no conflict between these different ways of trying to understand legal activity. The realist perspective simply offers a broader view. And it is this broader understanding of the legal terrain that this turn (back) to realism by programs such as the Agora represents. ${ }^{88}$

Any legal education that moves toward a focus on more than one jurisdiction begins to encounter the questions of not just geographic but also epistemic limits. When we think of law in a larger context we seem to invariably move towards a different sort of understanding. After a curriculum review, the professional program at McGill Law School began to describe itself as studying law from the perspective of "poly-jurality." In reflecting on this, despite lauding its goals of a wider perspective, Harry Arthurs seemed puzzled by the short shrift given to the problem of epistemic rather than geographic range. The McGill

\footnotetext{
${ }^{87}$ As we have already noted, the positivist theoretical model of law serves domestic practitioners, and would be practitioners, well, as a heuristic through which to focus the mind on the forms of legal validity recognized by domestic courts.

${ }^{88}$ As we noted above, the Agora is certainly not alone in advancing a model of transnational legal education. There are many programs at the professional and graduate levels that are concerned to move legal education beyond the confines of particular jurisdictions. Trans-jurisdictional education is, of course, nothing new. Legal education in federal states has always involved some element of trans- or poly-jurality. Colonialism has also frequently entailed the creation of new, though not wholly independent, jurisdictions, which has meant that legal education and practice has involved multiple jurisdictions. Contemporary transnational law programs tend to focus on more recent phenomena. The changing nature of the post-WWII international legal institutions towards the turn of the millennium are part of this (the growing importance of the WTO legally and institutionally, for instance, or the European Court of Human Rights). International law and legal institutions are increasingly not limited to inter-state relations, but penetrate into what was previously considered to be areas of state sovereignty. The rise of non-governmental law and regulation are also important in some conceptions of what the transnationalization of law is about.
} 
program has obvious drivers to its innovative approach. "It is a predominantly anglophone institution serving a declining anglophone population in an increasingly assertive francophone province. It has close affinities with legal education in common law North America, but is located in a jurisdiction one of whose defining characteristics is supposedly its civil law system." ${ }^{\prime 89}$ Along with these exigencies there is also an intellectual culture within the institution, according to Rod MacDonald, that is "characterized by a recurring preoccupation, in differing ways, with poly-jurality and non-state normativity, with transnational legal systems, and with legal theory." ${ }^{90}$

Despite this tradition, Arthurs found the program timid about its commitments. ${ }^{91}$ By focusing on "jurality" McGill has failed to give more heed to issues of interdisciplinarity, of the need to have some basic humanities and social science knowledge and their connection to the law as a way to help understand law in its context. "[I]nterdisciplinary perspectives help to rescue legal education and research from the tyranny of conventional assumptions, from the banality of legal-professional discourse, from the embarrassment of solipsistic or circular reasoning. ${ }^{\prime 22}$ Even if the curriculum review documents failed to highlight these commitments, members of the faculty might appreciate and pursue such goals. As McGill faculty member, and then Dean, Nicholas Kasirer made clear, the importance of the program was not in convincing law firms that recruits could function in different jurisdictions, but because it focuses on questions of "what explains law as a social phenomenon, what is the nature of legal knowledge, what does it mean to think like a lawyer, what it means to think like a citizen alive to law's symbolic and persuasive attributes.",93, ${ }^{44}$

Arthurs suggests that while many at McGill may have shared Kasirer's convictions about how to understand law and the importance of doing so, the failure to be both more explicit

\footnotetext{
${ }^{89}$ Harry Arthurs, Madly off in One Direction, 50 McGilL LAW JOURNAL 707 (2005), at 712.

${ }^{90}$ Id., at 713, summarizing MacDonald from, Roderick MacDonald, The National Law Programme at McGill: Origins, Establishment, Prospects, 13 Dalhousie LaW JouRnal 211 (1990).

${ }^{91} / d$., at 714 .

${ }^{92} / d$., at $716-717$.

${ }^{93}$ Nicholas Kasirer, Bijuralism in Law's Empire and in Law's Cosmos, 52 JouRnAL of LeGAL EdUCATION 29 (2002); cited in Arthurs at 717, supra note 89.

${ }^{94}$ In a similar vein Raymond Friel notes of the concept of educating a transnational lawyer that, "The aim of a transnational legal education is not to create individuals who can practice law in a number of diverse jurisdictions. Although graduates of such a program may well wish to do so, such an ability should not be seen as an objective in itself, but merely as an incidental result. The aim of such a program should be to create lawyers who are comfortable and skilled in dealing with the differing legal systems and cultures that make up our global community." Raymond J. Friel, Special Methods for Educating the Transnational Lawyer, 55 J. LeGAL EduCATION, 507, 507-508, (2005).
} 
and clearer about the need for an interdisciplinary view of the law was a shortcoming of the curriculum review. Arthurs notes that the term "“jural” shares the Latin root jus with scores of adjacent entries in the OED online", though strikingly in the middle of the list is the word Jurassic. He goes on to write:

Most people, many lawyers, even some McGill academics seem to view jurality in rather the same way: law - they imagine - has existed since "time immemorial"; it is the product of ineluctable natural processes; and its manifestations are awe-inspiring. Alas, it is the duty of legal academics, like geologists and archaeologists, to excavate mythologies, correct misconceptions, offer new hypotheses, test them against evidence, and revise them if they do not accurately describe what we understand to be reality. $^{95}$

The problem, then, is trying to do that in a way that remains fundamentally jural, that is, in a way that retains a perspective that is from within the law. The internal point of view that positivism focuses on does not offer sufficient perspective to truly understand law in its fullest sense. Arthurs' rather radical suggestion to this problem is a law curriculum that is deeply and committedly plural.

Legal pluralism might help to bridge the gap between interdisciplinarity and jurality. For the legal pluralists on the faculty, the "jural" and the "systemic" may refer not simply to common or civil or international law systems established by states, but as well to non-state normative regimes that are indigenous to all sites of social interaction - to workplaces, business networks, neighbourhoods, public bureaucracies, and religious communities. But if this were the case, the curriculum would be organized not around jural concepts - the Procrustean bed into which first year students are still firmly pressed - but rather around the varieties of social relationships that give rise to those concepts. Moreover, if these normative regimes were given curricular weight commensurate with their influence on social and legal behaviour and with the practical, intellectual, and ethical questions they raise, the criminal law syllabus would deal extensively with "the law of the courthouse," labour law with the "law of the shop," family law with "the law of the relationship," and so on. ${ }^{96}$

\footnotetext{
${ }^{95}$ Arthurs at 718 , supra note 89.

${ }^{96} / d$., at 718-719.
} 
Here we begin to see more clearly the idea to which Arthurs was giving voice in his GC2 session on the "construction of legal fields," legal education at length elsewhere. ${ }^{98}$ Despite his belief that the dominant view of polyjurality at McGill was likely of an archipelago of jurisdictions rather than "a way to cultivate an agnostic view of the claims to jurality itself and to explore the parallel normative universe that exists alongside law as it is conventionally understood by lawyers," ${ }^{99}$ he nonetheless lauded McGill's efforts at curriculum reform.

Much of the foregoing is applicable to the Agora and the idea of "transnational law." Arthurs expressed concern about the lack of specific commitment to a deeper critical project about law in the McGill curriculum review documents, but, if founding documents speak directly to the goals and directions of institutional arrangements, there may be hope in the Agora's MOU. While the "overarching theme" of the Agora is said to be the study of "law, change, and regulatory challenges in the contemporary world" the MOU goes on to note that it should be attentive to a short list of "organizing principles." ${ }^{100}$ These include:

b) Attentiveness to the permeability of different fields of law - as well as whole legal systems - to ideas, normative influences and structural forces that may previously have been thought of as marginal or largely external to those fields or systems; and c) The importance of critical inquiry and interdisciplinary perspectives on the nature of law, on law's content, and on law's role in different forms and spheres of regulation. ${ }^{101}$

The Agora in its first instantiation went a considerable way to creating an environment in which faculty and doctoral students could critically examine the assumptions of law, jurality, the internal point of view, what have you, and the accompanying myths of laws uniqueness in creating the normative worlds we inhabit. From our point of view it is certainly to be hoped that just such an impetus will remain a strong and central component of the program.

\footnotetext{
${ }^{97}$ See note 44 .

${ }^{98}$ Consultative Group on Research AND Education in LAW, LAW AND LeARning (1983) [Arthurs Report], Harry Arthurs lead author.

${ }^{99}$ Arthurs at 719 , supra note 89.

${ }^{100}$ MOU at 2, supra note 2.

${ }^{101} / d_{\text {., }}$ at 2 .
} 


\section{E. Conclusion}

The first installment of the annual Agora, this past July 2008, was a strong beginning for this valuable experiment in doctoral legal education. ${ }^{102}$ In the coming years the Agora will, no doubt, be subject to further experimentation and change. As we have indicated in the last section, we believe that there is a valuable theoretical and critical impetus to the program that we hope will continue to inform the Agora, and indeed, perhaps come in to even clearer focus. Ultimately, there is no tension between doctrinal work from the internal point of view, and a wider reaching critical legal pluralism, as long as their relationship to each other is understood. Indeed, appreciating the mythos of law, standing at the margin of law to better critically engage with law's claims, is best done via a thorough knowledge of law's claimed terrain. But as Arthurs notes about the McGill program, there is a risk that mapping that terrain may be mistaken for the job in full, if not by all participants in the process, then perhaps by some significant number. Such a result seems unlikely to transpire in the case of the Agora, though it bears saying that even understood in such a guise there would no doubt remain much of value in the Agora. The mere act of bringing together an international group of talented faculty and doctoral students of law for an intensive session of discussion around their areas of research and interest creates opportunities for enlightenment and edification. The efficacy of the Agora in this regard remains to be examined and re-examined with each of its instantiations and the testaments of their participants. We can look forward with great interest to the program and to reports of the next ATLAS Agora.

\footnotetext{
${ }^{102}$ The success of the initial installment came about only after many years of organizational efforts for which all those involved, too numerous to mention, should be congratulated.
} 
